Vol. 2 No.1, 1 April 2017

\title{
PENERAPAN STRATEGI IMAGINE DALAM MENINGKATKAN KEMAMPUAN MENULIS PUISI BEBAS PADA SISWA KELAS V SDN MURUNG RAYA 5 BANJARMASIN
}

\author{
Siti Aulia dan H. Kamal Hasuna \\ STKIP PGRI Banjarmasin \\ Email: sitiaulia@stkipbjm.ac.id.
}

\begin{abstract}
Abstrak
Hasil observasi pada SDN Murung Raya 5 Banjarmasin, ditemukan rendahnya kemampuan menulis puisi bebas, penyebabnya adalah penggunaan strategi pembelajaran yang kurang tepat sehingga pembelajaran kurang berjalan dengan maksimal dan optimal. Oleh karena itu penting dilakukan perbaikan melalui penelitian tindakan kelas (PTK) dengan menerapkan strategi imaginedengan tujuan untuk meningkatkan aktivitas dan hasil belajar siswa yang dilaksanakan dalam dua siklus dimana tiap-tiap siklus terdiri dari dua kali pertemuan dan tiga kali pertemuan. Subjek penelitian adalah siswa kelas V SDN pelambuan 7 Banjarmasin yang berjumlah 12 orang, yang terdiri dari 6 orang laki-laki dan 6 orang perempuan. Sumber data diperoleh dari guru dan siswa yang berupa data kuantitatif dan kualitatif. Data aktivitas guru dan data aktivitas siswa diperoleh melalui obsevasi yang direkamkan pada lembar observasi serta data hasil belajar siswa diperoleh melalui evaluasi hasil kerja siswa. Hasil penelitian menunjukkan bahwa aktivitas guru, aktivitas siswa, serta hasil belajar siswa meningkat melalui penerapan strategi imagine. Oleh karena itu disarankan kepada guru, agar secara bertahap dan berkesinambungan mengkaji pola dan strategi pembelajaran yang tepat dalam upaya perbaikan proses dan hasil pembelajaran dimana salah satunya adalah startegi Imagine yang telah terbukti dapat meningkatkan aktivitas dan hasil belajar siswa.
\end{abstract}

Kata Kunci: kemampuan menulis, puisi bebas, strategi imagine.

\section{PENDAHULUAN}

Belajar bahasa bertujuan meningkatkan kemampuan keterampilan komunikasi dalam berbagai konteks komunikasi. Kemampuan yang dikembangkan adalah daya tangkap makna, peran, daya tafsir, menilai dan mengekspresikan diri dengan berbahasa.

Pembelajaran bahasa Indonesia di sekolah dasar menetapkan kompetensi keterampilan berbahasa yang harus dikuasai siswa, yaitu keterampilan menyimak (listening skill), berbicara (speaking skill), membaca (reading skill), dan menulis (writing skill).

Menulis ialah menurunkan atau melukiskan lambang-Iambang grafik yang menggambarkan suatu bahasa yang dipahami oleh seseorang, sehinggaa orang-orang' lain dapat membaca grafik tersebut, kalau mereka memahami bahasa dan grafik tersebut (Tarigan, 2000:21). 
Vol. 2 No.1, 1 April 2017

Perkembangan bahasa tulis dan kegiatan cetak mencetak menuntut para pendukungnya mengembangkan tradisi menulis dan membaca. Tradisi menulis dapat diartikan sebagai kebiasaan untuk menyatakan gagasan atau pendapat secara tertulis, sedangkan membaca merupakan kebiasaan orang untuk memanfaatkan tulisan dalam rangka mengembangkan pengetahuan. Telah disadari betul bahwa penguasaan membaca dan menulis sangat diperlukan dalam kehidupan sekarang, tetapi pada kenyataannya keterampilan-keterampilan tersebut masih kurang diperhatikan, misalnya saja pelajaran mengarang dan menulis puisi sebagai salah satu aspek dalam pengajaran bahasa Indonesia kurang ditangani sungguh-sungguh. Guru hanyyaa menugaskan siswanya untuk membaca puisi sebatas kemampuan siswanya tersebut tanpa ada bimbingan terencana dari guru, bahkan guru sering melewatkan pembelajaran menulis puisi. Akibatnya kemampuan keterampilan menulis kurang memadai.

Pendidikan masih dipandang seperangkat fakta-fakta yang harus dihapal, dan kelas masih berpusat bahwa guru sebagai sumber utama pengetahuan, akhirnya metode ceramah sebagai strategi pembelajaran. Untuk itu diperlukan strategi yang tidak mengharuskan menghapal kata-kata, tetapi mendorong siswa untuk mengkonstruksikann pengetahuan dalam pikiran mereka sendiri.

Pembelajaran puisi dianggap sulit diterapkan oleh guru dan sulit untuk dipahami siswa. Bagi guru sulit diterapkan karena guru tidak menguasai teknik pembelajaran yang dapat membangkitkan minat dan semangat siswa untuk menciptakan ide-ideenya sendiri yang nantinya akan dituangkan ke dalam sebuah tulisaan, yaitu berupa puisi. Bagi siswa sendiri sulit untuk dipahami karena kurangnya kreativitas siswa dalam menciptakan dan membangun imajinasinya.

Jika bercermin dari kenyataan di lapangan selama ini, pembelajaran menulis puisi masih akan tetap menjadi persoalan besar jika tidak ditangani dengan baik. Menulis puisi akan menjadi hal yang menakutkan bagi siswa, dan guru pun tidak pernah memberikan bimbingan kepada siswa untuk menciptakan ide-idenya sendiri sebagai penunjang untuk menulis puisi yang benar.

Konsep pembelajaran dengan menggunakan strategi imagine (khayalan visual) artinya dimana siswa akan dilatih untuk membuka mata pikiran mereka dan akan dibimbing oleh guru, agar tercipta khayalan yang akan mereka bangun sendiri untuk dituangkan atau ditulis ke dalam sebuah puisi.

Melalui khayalan visual, peserta didik dapat menciptakan ide-idenya sendiri. Khayalan itu efektif sebagai suplemen kreatif pada belajar kolaboratif (Silberman, 2007:183).

Melalui penelitian ini penulis mengharapkan dengan menggunakan strategi dan teknik pembelajaran yang tepat, siswa dapat menciptakan idenya untuk dituangkan dalam sebuah tulisan berupa puisi bebas sesuai tingkat pemikiran siswa kelas V.

Dari kenyataan tersebut maka pembelajaran menulis puisi bebas dapat dilaksanakan dengan menggunakan strategi imagine sebagai pemecah masakah yang dihadapi. Diharapkan dengan kegiatan yang direncanakan dan dilaksanakan sesuai prosedur nantinya dapat mencapai hasil yang diharapkan. Adapun rumusan masalah pada penelitian ini: 1) Apakah terdapat peningkatan aktivitas 
Vol. 2 No.1, 1 April 2017

siswa dalam pembelajaran tentang menulis puisi bebas di kelas V SDN Murung Raya 5 Banjarmasin melalui strategi imagine (khayalan visual), 2) Bagaimana aktivitas guru dalam melaksanakan pembelajaran menulis puisi bebas di kelas $\mathrm{V}$ SDN Murung Raya 5 Banjarmasin melalui strategi imagine (khayalan visual)?, 3) Apakah terdapat peningkatan hasil belajar siswa kelas $\mathrm{V}$ dalam menulis puisi bebas dengan menggunakan strategi imagine (khayalan visual) di SDN Murung Raya 5 Banjarmasin?

\section{METODE}

Penelitian ini dilaksanakan di SDN Murung raya 5 , subjek dalam penelitian ini adalah siswa kelas $\mathrm{V}$ yang berjumlah 12 orang yang terdiri dari 6 orang siswa lakilaki dan 6 orang siswa perempuan. Penelitian yang akan dilaksanakan adalah Penelitian Tindakan Kelas (PTK), yang dilakukan dalam dua siklus, setiap siklus terdiri dari 2 kali pertemuan. PTK dilaksakan secara berkesinambungan di mana setiap siklus mencerminkan peningkatan atau perbaikan. Siklus sebelumnya merupakan patokan untuk siklus selanjutnya. Sehingga diperoleh model pembelajaran yang paling baik (Daryanto,2011:6). PTK bersifat fleksibel sehingga mudah diadaptasikan dengan keadaan kelas. Dengan demikian proses pembelajaran tidak monoton oleh satu model saja (Tahir,2012:81) Alur penelitian tindakan kelas sebagai berikut:

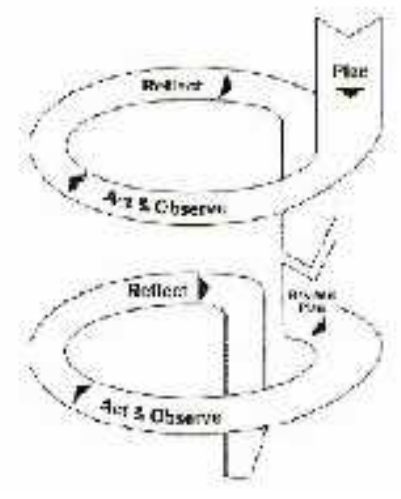

Gambar 1. Alur PTK (Kemmis and Taggart, 1988:11)

Teknik yang digunakan dalam pengumpulan data dalam penelitian ini adalah observasi dan tes. Test digunakan untuk mengukur keberhasilan hasil belajar siswa dan observasi dilakukan untuk mengukur aktivitas siswa dalam pembelajaran. Tehnik analisa data dalam penelitian ini dilakukan dengan reduksi data, paparan data dan menarik kesimpulan. Indikator dari keberhasilan penelitian tindakan kelas ini jika adanya peningkatan dari hasil evaluasi dan observasi terhadap siswa. Apabila nilai atau hasil belajar siswa mencapai ketuntasan belajar baik secara individual maupun klasikal, maka penelitian tindakan kelas ini dianggap berhasil. Secara individual, ketuntasan belajar tercapai jika siswa mendapatkan nilai lebih dari atau sama dengan 66,67 . Ketuntasan belajar klasikal tercapai yaitu apabila terdapat 66,67 \% siswa yang 
memiliki penguasaan minimal lebih besar atau sama dengan 66,67 (Depdiknas, 2003:12).

\section{MENULIS PUISI BEBAS}

\section{Pembelajaran Menulis}

Pembelajaran menulis tidak dapat dipisahkan dari kegiatan bahasa lainnya Menulis didorong oleh kegiatan berbicara, mendengarkan dan membaca. Kemampuan atau keterampilan menulis adalah kemampuan mengungkapkan gagasan, pendapat perasaan kepada pihak lain dengan melalui bahasa tulis. (Abbas, 2006:125)

Menurut Siddik dan Musaba (2010:4), Keterampilan menulis merupaka proses komunikasi. Keterampilan berbahasa ini bisa diartikan sebagai wujud kemampuan dalam berkomunikasi, lebih singkat lagi dapat dikatakan bahwa berbahasa berarti berkomunikasi atau melakukan hubungan antar manusia.

Adapun manfaat menulis menurut Suparno dan Yunus (2009: 1.4) itu diantaranya dalam hal:

1. Peningkatan kecerdasan

2. Pengembangan daya inisiatif dan kreativitas

3. Pertumbuhan keberanian

4. Pendorong kemauan dan mengumpulkan informasi.

Kegiatan menulis yang dikembangkan dan dilaksanakan di sekolah dasar adalah:

\section{Menulis Permulaan}

Dalam pembelajaran menulis permulaan tentu harus dimulai pada hal sangat sederhana. Menulis tentu hanya dengan beberapa kalimat sederhana bukan suatu karangan yang utuh. Mengajarkan menulis permulaan tentu saja selalu dilakukan dengan menulis permulaan seperti berikut. (a) mengarang mengikuti pola dengan cara siswa hanya diminta membuat karangan seperti contoh (pola) yang diberikan yang tentunya idenya harus lebih dekat dengan siswa. Hal ini dimaksudkan agar siswa dapat menuangkan ide/pikiran secara runtut dan logis. Contoh: Jeruk.

Jeruk berbentuk bulat.

Isinya kuning.

Rasanya manis dan asam.

Jeruk banyak dijual di pasar.

Contoh diatas dapat ditiru polanya oleh anak dengan memberi topik lain misalnya kelereng, kucing, pohon, dan sebagainya. Karangan di atas bisa diajarkan pada kelas satu dan dua, setelah siswa lancar dalam menulis kalimat sederhana. (b) Mengarang dengan melengkapi kalimat, yakni siswa diminta untuk melengkapi kalimat dalam karangan dengan kata yang telah tersedia. (c) Bimbingan dengan memasangkan kelompok kata, yakni siswa diminta untuk memasangkan kelompok kata dengan kalimat yang terpenggal atau kurang lengkap. Hal ini bertujuan agar siswa dapat membuat kalimat luas. (d) Bimbingan dengan mengurutkan 
Vol. 2 No.1, 1 April 2017

kalimat, yaitu siswa dibimbing untuk mengurutkan kalimat sesuai dengan gambar seri. (e) Bimbingan dengan pertanyaan, hal ini diharapkan agar siswa dapat membuat karangan setelah dimulai dengan pertanyaan-pertanyaan dalam pikirannya. Karena sebuah karangan jika ditarik kesimpulan sebenarnya merupakan rangkaian jawaban atas berbagai pertanyaan. Dalam hal ini guru hanya menyiapkan beberapa pertanyaan, misalnya: Kucingku; apa nama kucingmu, apa warnanya, apakah kamu menyukainya, apa makanannya, kapan memberi makan, lucukah, mengapa lucu, bagaimana suaranya, mengapa kucing dipelihara orang, dan sebagainya.

Demikian beberapa contoh mengarang atau menulis permulaan, yang pada dasarnya merupakan upaya membentuk kebiasaan siswa mengarang secara sederhana sesuai dengan tingkat perkembangan kemampuannya. (Abbas, $2006: 126$ ).

\section{Menulis Lanjutan}

Syarat untuk dapat menulis lanjutan adalah siswa harus terampil dan menguasai menulis permulaan. Oleh karena itu, pada prinsipnya menulis lanjutan adalah pengembangan menulis permulaan. Adapun tujuannya adalah agar siswa dapat menulis karangan secara ajek dan lengkap. Beberapa metode dalam menulis lanjutan antara lain: (a) Membuat paragraf dengan gambar, yakni siswa diminta untuk membuat paragraf berdasarkan gambar yang telah disediakan. Hal ini dapat diberi katakata kunci, sehingga tidak terlalu menyimpang dengan cerita. (b) Mengembangkan paragraf, yakni siswa dilatih untuk mengembangkan sebuah kalimat utama menjadi sebuah paragraf.(c) Menyusun paragraf dari kalimat yang tersedia. (d) menghubungkan paragraf dengan paragraf lainnya. (e) Membuat karangan dengan gambar seri. (f) Mengarang berdasarkan kerangka, dan mengarang secara bebas.

Kesemua metode diatas bukanlah harga mati melainkan sangat fleksibel. Hal ini disebabkan karena pembelajaran menulis di SD cakupannya cukup luas. Adapun ruang lingkup pembelajaran menulis/mengarang di SD antara lain adalah mengarang prosa narasi, menulis prosa deskripsi, menulis surat izin, menulis surat undangan, mengisi formulir, menyusun paragraf, mengembangkan judul dan topik, menulis nonfiksi, menyingkat cerita, menyusun naskah pengumuman, menyusun iklan dan poster, menulis laporan kegiatan, menyusun naskah pidato dan lain-lain. Upaya yang dapat dilakukan guru agar siswa senang menulis adalah memberi kebebasan kepada siswa untuk mau menulis apa yang disenanginya sesuai dengan pengembangan tema pembelajaran yang dilaksanakan. (Abbas, 2006:127).

\section{Puisi}

Pada umumnya para penyair akan mengatakan "puisi mengajarkan sebanyak mungkin dengan kata atau kombinasi kata sesedikit mungkin”. 
Vol. 2 No.1, 1 April 2017

Dengan kata lain dengan kata-kata yang sesedikit mungkin ingin melukiskan/mengajarkan atau mengatakan sesuatu dengan jelas dan seluas mungkin. Tetapi yang penting disini yaitu: bila untuk memecahkan maksud di atas maka mau tidak mau diperlukan suatu metode yang baik beserta sarana-sarana yang diperlukan, yaitu:

- Diksi (diction): pilihan kata

- Imaji (Imagary): segala sesuatu yang dialami secara imajinatif.

- Kata nyata (concrete): kata yang konkrit dan khusus.

- Majas (figurative language): bahasa kias atau gaya bahasa.

- Ritme (irama): turun naiknya suara secara teratur.

- $\quad$ Rima (sajak): persamaan bunyi. (Tarigan, 2000:28)

Puisi bebas adalah bentuk puisi yang tidak terikat oleh jumlah baris, suku kata juga rimanya. Langkah-langkah menulis puisi bebas :

1. Amati objek yang akan ditulis.

2. Tentukan temanya.

3. Tuliskan atau kembangkan tema tersebut menjadi judul puisi.

4. Kembangkan menjadi cerita yang bentuknya puisi.

5. Susunlah tiap kalimat berurutan ke bawah, satu baris berisi satu kalimat yang tidak terlalu panjang.

6. Jika ada kalimat yang panjang, perpendeklah dengan membuang kata tugas atau menjadikan kalimat-kalimat ini.

7. Carilah kalimat atau kata yang bisa diganti dengan kata yang memiliki intensitas makna lebih kuat dan lebih imajinatif, misalnya matahari diganti dengan sang surya, mentari dan lain-lain.

8. Perbaiki terus kata tiap kalimat jika dianggap kurang memenuhi keindahan bunyi boleh juga menggunakan gaya bahasa. (Tarigan, 2000:12)

\section{Strategi Imagine}

Strategi merupakan usaha untuk memperoleh kesuksesan dan keberhasilan dalam mencapai tujuan. Strategi pembelajaran dapat diartikan sebagai perencanaan yang berisi tentang rangkaian kegiatan yang didesain untuk mencapai tujuan pendidikan tertentu. Strategi pembelajaran merupakan rencana tindakan (rangkaian kegiatan) termasuk penggunaan metode dan pemanfaatan berbagai sumber daya atau kekuatan dalam pembelajaran yang disusun untuk mencapai tujuan tertentu. Menurut Dharma Surya (2008), strategi dapat diartikan sebagai suatu garis-garis besar haluan untuk bertindak dalam rangka mencapai sasaran yang telah ditentukan. Dikaitkan dengan belajar mengajar, strategi bisa diartikan pola-pola umum kegiatan guru, murid dalam perwujudan kegiatan belajar mengajar untuk mencapai tujuan yang telah ditentukan. (http://www.teknologipendidikan.net, diakses 25 Januari 2016).

Strategi imagine merupakan strategi yang mengaktifkan siswa dari khayalan visual peserta didik itu sendiri untuk menciptakan ide-idenya. Karena melalui khayalan itu efektif sebagai suplemen kreatif untuk peserta didik pada belajar 
kolaboratif. Dl strategi ini peserta didik akan diberikan stimulus dan bimbingan untuk menciptakan dan membangun ide-ide mereka yang akan mereka ceritakan atau mereka tuangkan dalam sebuah tulisan berupa puisi.

Tahap intelektual (antara umur 7 tahun s.d. 12 tahun) dalam tahap ini, fungsi ingatan, imajinasi dan pikiran pada anak mulai berkembang. (Djaali, 2008:25)

Pada usia peserta didik 7 s.d. 12 tahun fungsi ingatan, imajinasi dan pikiran pada anak mulai berkembang. Disaat perkembangan ini akan dilatih untuk menggali pikirannya dari imajinasi anak, sehingga apa yang nantinya akan anak tulis sesuai dengan hasil pemikirannya. Disini guru sebagai fasilitator yang akan memberikan bimbingan kepada peserta didik untuk mencoba menciptakan dan membangun idenya.Strategi yang menekankan kepada siswa untuk menciptakan dan membangun idenya sendiri dan guru sebagai fasilitator dan pembimbing bagi siswa untuk belajar. Langkah-langkah strategi imagine yaitu :

1. Memperkenalkan topik yang akan dicakup.

2. Menjelaskan kepada peserta didik bahwa pelajaran menuntut kreativitas dan penggunaan khayalan visual bisa membantu usaha mereka.

3. Menginstruksikan kepada kelas untuk menutup mata mereka.

4. Meminta peserta didik, dengan matanya yang tertutup untuk mencoba memvisualisasikan cahaya dan suara seperti kuntum bunga, kamar tidur mereka, lampu lalu lintas yang berubah atau rintik hujan.

5. Ketika anggota kelas rileks, guru menyiapkan satu khayalan bagi siswa untuk dibangun. Misalnya kereta api yang sedang melaju.

6. Ketika khayalan dilukiskan, siapkan jarak sunyi sehingga peserta didik dapat membangun khayalan visual mereka sendiri. Susun pertanyaanpertanyaan yang mendorong penggunaan panca indra, seperti:

- la terlihat seperti apa?

- Bagaimana bunyinya?

- Siapa yang kamu lihat disana?

- Apa saja yang dilewati kereta tersebut?

- Apa yang kamu rasakan?

7. Simpulkan panduan khayalan dan instruksikan kepada anggota kelas untuk mengingat khayalannya.

8. Dengan perlahan akhiri latihan.

9. Mintalah peserta didik untuk membentuk kelompok-kelompok kecil dan saling membagi pengalamannya. Minta mereka untuk melukiskan khayalan kepada yang lainnya dengan menggunakan panca indra sebanyak mungkin. Dan minta mereka untuk menuliskan tentang khayalannya. (Silberman, 2007:183)

Kelebihan strategi Imagine:

1. Akan membuat pembelajaran lebih menarik dan kreatif serta menarik minat siswa dengan kegiatan menggunakan khayalan visual.

2. Stimulus yang jelas dari guru mempermudah siswa menggunakan imajinasinya untuk membangun khayalan. 
- Siswa akan lebih mudah menuliskan hasil ciptaan ide-ide dengan bimbingan guru.

\section{HASIL DAN PEMBAHASAN}

Berdasarkan hasil penelitian yang disajikan, dapat dikemukakan pembahasan sebagai berikut :

1. Aktivitas siswa

Aktifitas siswa dalam pembelajaran dengan menggunakan strategi imagine cukup mendukung dan aktif, hal ini dilihat pada :

a. Peningkatan belajar siswa yang mengalami peningkatan. Bila dikemukakan dalam bentuk grafik sebagai berikut :

Grafik 1. Nilai rata-rata tiap pertemuan

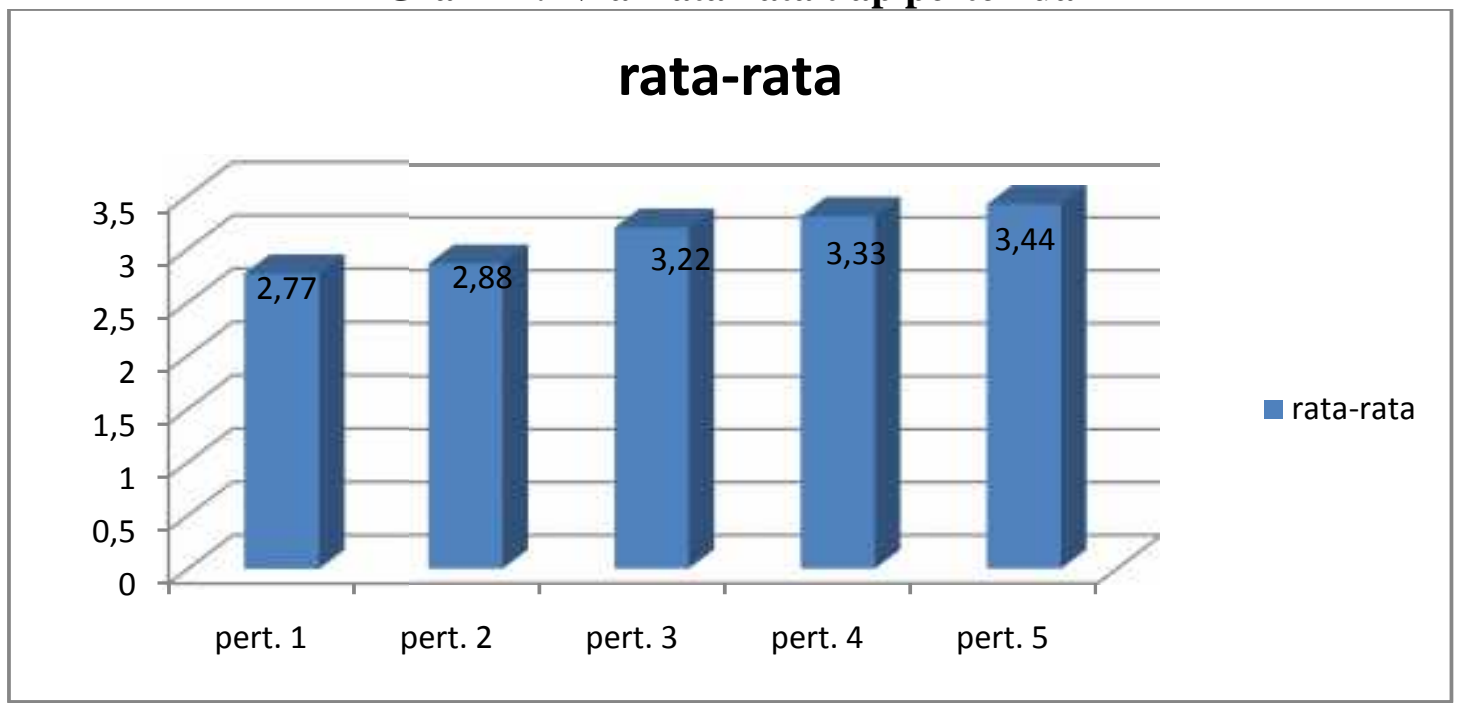

Dalam proses pembelajaran dengan menggunakan strategi imagine sesuai dengan teori belajar konstruktivisme. Penerapan konstruktivisme dalam proses belajar-mengajar menghasilkan metode pengajaran yang menekankan aktivitas utama pada siswa. Teori pendidikan yang didasari konstruktivisme memandang murid sebagai orang yang menanggapi secara aktif objek-objek dan peristiwa-peristiwa dalam lingkungannya, serta memperoleh pemahaman tentang seluk-beluk objek-objek dan peristiwa-peristiwa itu (Ahmadi dkk, 2004 : 219).

Menurut teori ini, perlu disadari bahwa siswa adalah subjek utama dalam kegiatan penemuan pengetahuan. Mereka menyusun dan membangun pengetahuan melalui berbagai pengalaman yang memungkinkan terbentuknya pengetahuan. Mereka harus menjalani sendiri berbagai pengalaman yang pada akhirnya memberikan percikan pemikiran tentang pengetahuan-pengetahuan tertentu. Hal terpenting dalam pembelajaran adalah siswa perlu menguasai bagaimana caranya belajar. Dengan itu, ia bisa jadi pembelajar mandiri dan menemukan sendiri pengetahuan-pengetahuan yang ia butuhkan dalam kehidupan. 
Menurut Ausubel, belajar dapat diklasifikasikan ke dalam dua dimensi, dimensi pertama berhubungan dengan cara informasi atau materi pelajaran disajikam pada siswa, melalui penerimaan atau penemuan. Dimensi kedua menyangkut cara bagaimana siswa dapat mengaitkan informasi itu pada struktur kognitif yang telah ada (Dahar, 2006 : 134).

Struktur kognitif ialah fakta-fakta, konsep-konsep dan generalisasigeneralisasi yang telah dipelajari dan diingat oleh siswa. Pada tingkat pertama dalam belajar, informasi dapat dikomunikasikan pada siswa baik dalam bentuk belajar penemuan yang menyajikan informasi itu dalam bentuk final, maupun dengan bentuk belajar penerimaan yang mengharuskan siswa untuk menemukan sendiri sebagian atau seluruh materi yang akan diajarkan. Dalam tingkat kedua, siswa menghubungkan atau mengaitkan informasi itu pada pengetahuan yang telah dimilkinya dalam hal ini terjadi belajar bermakna. Akan tetapi, siswa itu dapat juga hanya mencoba-coba menghafalkan informasi baru itu, tanpa menghubungkannya pada konsep-konsep yang telah ada dalam struktur kognitifnya; dalam hal ini terjadi belajar hafalan.

2. Aktifitas guru

Pelaksanaan pembelajaran oleh guru terus mengalami peningkatan, berikut disajikan grafik peningkatan pelaksanaan pembelajaran :

Grafik 2. Aktifitas pelaksanaan pembelajaran oleh guru

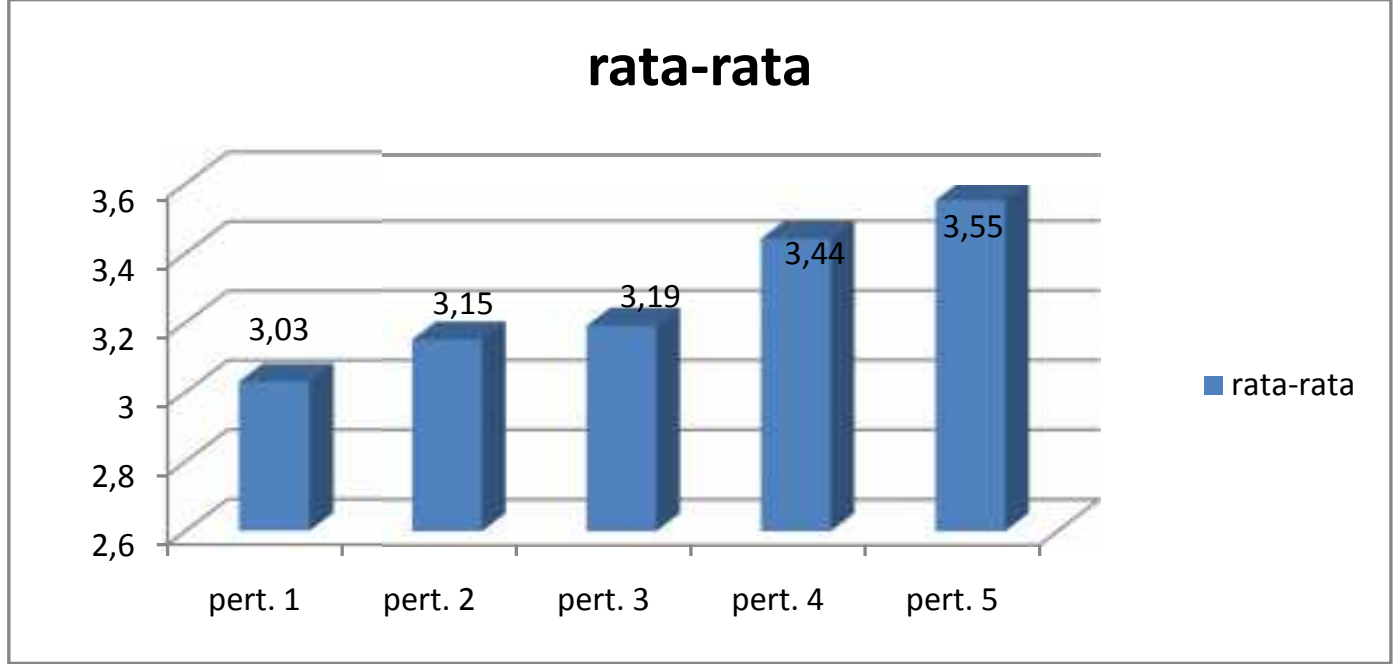

Konstruktivisme memandang belajar sebagai proses dimana pembelajar secara aktif mengkonstruksi atau membangun gagasan-gagasan atau konsep-konsep baru didasarkan atas pengetahuan yang telah dimilkinya di masa lalu atau ada pada saat itu. Dengan kata lain belajar melibatkan konstruksi pengetahuan seseorang dari pengalamannya sendiri oleh dirinya sendiri.

http://en.wikipedia.org/wiki/Constructivism_(psychology).html.

( Diakses 12 Maret 2016).

Dalam pembelajaran ini guru hanyalah sebagai fasilitator dimana guru akan bertindak sebagai pemberi stimulus dan siswa dapat merespon stimulus 
tersebut. Menurut Thorndike, belajar adalah proses interaksi antara stimulus dan respon. Stimulus adalah apa yang merangsang terjadinya kegiatan belajar seperti pikiran, perasaan, atau hal-hal lain yang dapat ditangkap melalui alat indera. Sedangkan respon adalah reaksi yang dimunculkan peserta didik ketika belajar, yang dapat pula berupa pikiran, perasaan, atau gerakan/tindakan. Jadi perubahan tingkah laku akibat kegiatan belajar dapat berwujud konkrit, yaitu yang dapat diamati, atau tidak konkrit yaitu yang tidak dapat diamati.

(http: //id.wikipedia.org/wiki/Teori_Belajar_Behavioristik. (Diakses 12 Maret 2016)

3. Hasil belajar

Tingkat ketuntasan belajar pada masing-masing pertemuan mengalami peningkatan hasil belajar. Bila disajikan dalam bentuk grafik sebagai berikut :

\section{Grafik 10. Ketuntasan belajar tiap pertemuan}

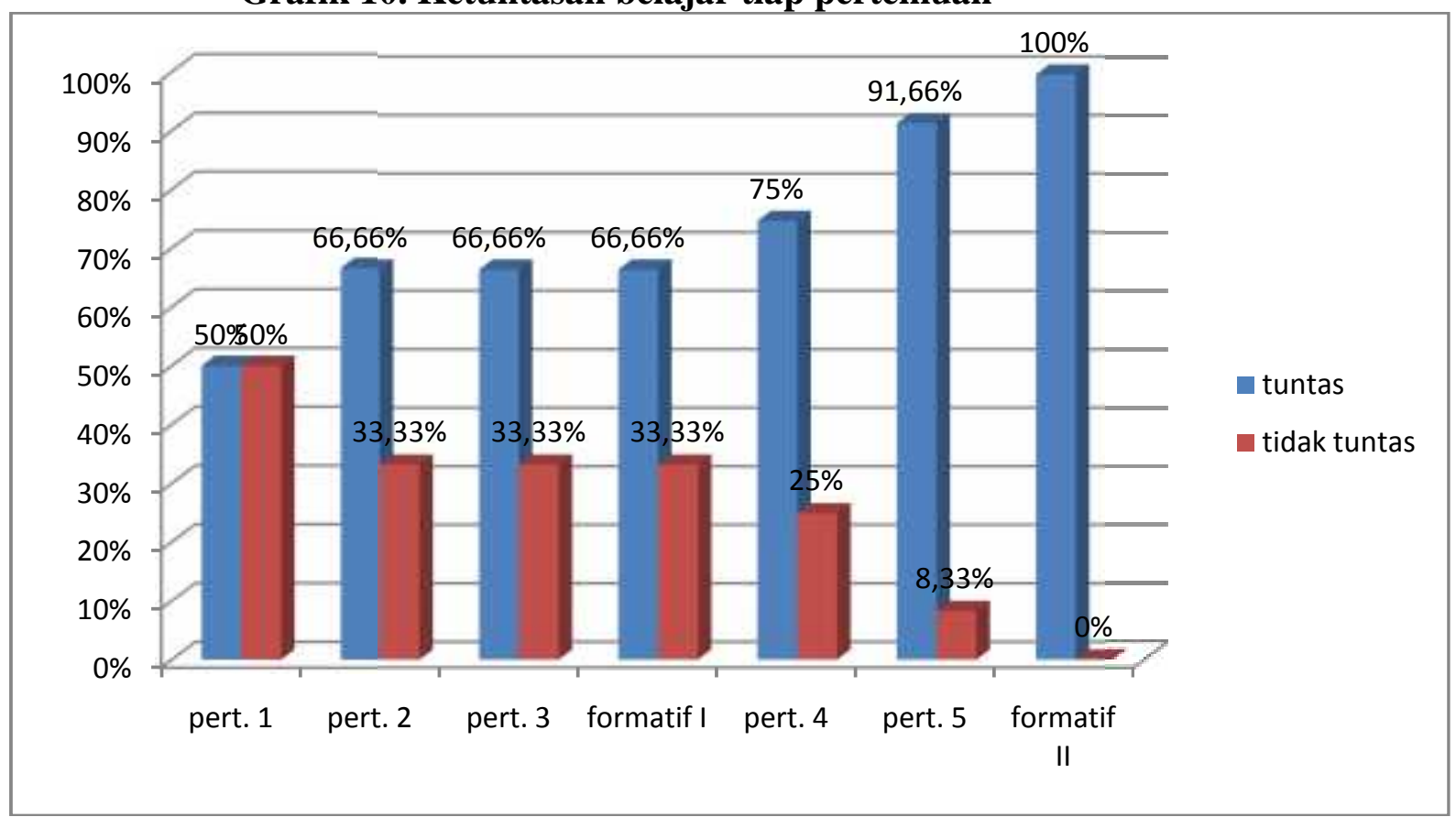

Berdasarkan temuan tersebut, maka ketuntasan belajar secara individu siklus II meningkat dibandingkan dengan ketuntasan belajar secara individu pada siklus I. Peningkatan ini disebabkan pelaksaan strategi imagine pada mata pelajaran Bahasa Indonesia di kelas V SDN Murung Raya 5 Banjarmasin. Dengan demikian hipotesis yang berbunyi, "Apabila menggunakan startegi imagine maka kemampuan menulis puisi kelas V SDN Murung Raya 5 Banjarmasin dapat meningkat". Hal ini sejalan dengan pendapat ahli bahwa melalui imagine (khayalan visual), peserta didik dapat menciptakan ide-idenya 
Vol. 2 No.1, 1 April 2017

sendiri. Khayalan itu efektif sebagai suplemen kreatif pada belajar kolaboratif. (Silberman, 2007:183).

Pendapat ini di dukung oleh (Djaali, 2008: 25) tahap intelektual (antara umur 7 tahun s.d. 12 tahun), fungsi ingatan, imajinasi dan pikiran pada anak mulai berkembang. Disaat perkembangan inilah dilatih untuk menggali pikirannya dari iamjinasi anak, sehingga apa yang nantinya akan anak tulis sesuai dengan hasil pemikirannya. Dan hal lain yang terpenting adalah memberikan kebebasan kepada anak untuk mau menulis apa yang disenanginya sesuai dengan pengembangan tema pembelajaran yang dilaksanakan (Abbas, 2006:127).

\section{PENUTUP}

\section{SIMPULAN}

Berdasarkan hasil dan pembahasan penelitian di atas dapat disimpulkan sebagai berikut: 1) Aktivitas siswa dalam pembelajaran tentang menulis puisi bebas di kelas V SDN Murung Raya 5 Banjarmasin meningkat setelah guru menerapkan strategi imagine, 2) Aktivitas guru dalam pelaksanaan pembelajaran menulis puisi bebas di kelas V SDN Murung Raya 5 Banjarmasin mengalami peningkatan setelah menerapkan strategi imagine, 3) Hasil belajar dam pembelajaran menulis puisi bebas di kelas V SDN Murung Raya 5 Banjarmasin mengalami peningkatan. Hal ini terlihat pada rekapitulasi hasil belajar siswa, yang mana pada siklus I yang tuntas $66,66 \%$ (8 orang) dan pada siklus II yang tuntas mencapai $100 \%$ (12 orang).Jadi penggunaan strategi imagine dapat meningkatkan hasil belajar atau meningkatkan kemampuan siswa menulis puisi bebas di kelas V SDN Murung Raya 5 Banjarmasin.

\section{SARAN}

Sebaiknya penerapan strategi pembelajaran seperti imagine dilakukan sebelum penelitian secara berulang-uulang oleh guru, sebelum itu pula guru telah dibekali dan diberi penjelasan secara jelas mengenai sttrategi pembelajaran yang akan diterapkan, sehingga pada saat penelitian siswa tidak bingung dan ribut saat bergeser. Aktivitas belajar sangatlah penting, karena keterlibatan siswa sangat berperan dalam mencapai tujuan pembelajaran. Dan itu semua akan mempengaruhi dari hasil belajar siswa itu sendiri. Hasil belajar yang telah dicapai siswa sebaiknya dipertahankan dan semakin ditingkatkan untuk mata pelajaran Bahasa Indonesia. Sedangkan kesulitan yang dihadapi dalam penerapan perpaduan kedua model ini harus diperkecil dengan cara membuat aturan-aturan yang jelas seperti memberikan tanda pada masing-masing daerah lingkaran serta diberikan tanda sebagai arah untuk bergeser pada saat berhadapan. Dan menyediakan fasilitas belajar lainnya untuk membuat peta konsep yang indah, beragam dan menarik tentunya 
Vol. 2 No.1, 1 April 2017

\section{DAFTAR PUSTAKA}

Abdulhak, I. (2000). Ilmu dan Aplikasi Pendidikan. Jakarta : Grafindo

Anita, L. (2008). Cooperative Learning: Mempraktikkan Cooperative Learning di ruang-ruang Kelas. Jakarta: Grasindo

Badan Nasional Standar Pendidikan. (2009). Undang-Undang No. 20 Tahun 2003 tentang Sistem Pendidikan Nasional. Surabaya: Wacana Intelektual

Daryanto. (2011). Penelitian Tindakan Kelas dan Penelitian Tindakan Sekolah. Yogyakarta: Gava Media

Dimyati \& Mudjiono. (2006). Belajar dan pembelajaran. Jakarta: Rineka Cipta

Kemmis, S \& McTaggart, R. (1983). The Action Research Planner. $3^{\text {rd }}$ ed. Victoria. Australia: Deakin University

Pembukaan Undang-Undang Dasar Negara Republik Indonesia 1945

Porter, D. B. \& Hernacki. (2008). Quantum Learning: Membiasakan Belajar Nyaman dan Menyenangkan. Bandung: Kaifa

Rusdayanto, F. (2010). Potret Buram Pendidikan Kita. Jakarta: PT. Pena Emas

Sanjaya, W. (2010). Penelitian Tindakan Kelas. Jakarta: Kencana Prenada Media Group

Sudjana, N. (2009). Dasar-Dasar Proses Belajar Mengajar. Bandung: Sinar Baru Algensindo

Suprijono, A. (2009). Cooperative Learning : Teori dan Aplikasi PAKEM. Yogyakarta : Pustaka Pelajar.

Suprijono, A. (2012). Cooperatif Learning. Jakarta: Kencana Yudistira 